\title{
Sprawozdanie z I Studenckiej Międzynarodowej Konferencji Edukacyjnej „We are the Pioneers", Vaasa, 5 grudnia 2016 roku
}

DOI: 10.14746/BHW.2016.35.15

W dniu 5 grudnia 2016 r. pod patronatem Rektora Åbo Akademi w Finlandii Mikko Hupa odbyła się pierwsza Studencka Międzynarodowa Konferencja Naukowa „We are the Pioneers" zorganizowana przez Dział Zagraniczny Åbo Akademi w Vaasa. Tegoroczny temat konferencji dotyczył innowacyjnych metod nauczania, które warto naśladować w praktyce edukacyjnej.

Konferencja została oficjalnie otwarta przez Koordynatora Działań Międzynarodowych Åbo Akademi w Vaasa, Susanne Nylund-Torp. Przywitała ona studentów z całego świata wraz z zaproszonymi wykładowcami oraz wyraziła swoje zadowolenie i uznanie wobec odbywającego się wydarzenia. Pani Nylund-Torp w swojej przemowie podkreśliła, że taka konferencja odbywa się po raz pierwszy i zwróciła uwagę na jej wielki sukces oraz zainteresowanie, z jakim się spotkała. Podkreśliła również rolę międzynarodowych studentów w kreowaniu rzeczywistości naukowej, a także ich zaangażowanie w innowacyjny rozwój i funkcjonowanie edukacji.

Pierwszym punktem konferencji był wykład Doktor Mikaeli Hermans pod tytułem „Climate Change Education”. Dotyczył on zmian klimatycznych, które znacząco wpływają obecnie na jakość procesu edukacji. Po zakończeniu wykładu nastąpił czas na obrady plenarne, które zostały zorganizowane w dwóch częściach. W pierwszej części wygłoszone zostały referaty z Polski, Niemiec oraz Wietnamu. Wszystkie prezentacje odbyły się w języku angielskim oraz $\mathrm{z}$ elementami języków narodowych. Prezentacje zostały przygotowane przez następujące osoby: Jakub Karol Adamczewski, Radio programmes for children in Polish educational history; Elena Boos, Lisa Wittmeyer, Kubra Sahin, Dorothee Louison Eiffler, Annemarie Wehner, After-school activities in German educational system; Thuy Hang Vuong, Vietnamese and Finnish educational system comparative analysis. Na zakończenie pierwszej części wystąpień odbyła się dyskusja dotycząca wygłoszonych przemówień, która moderowana była przez prelegentów.

Druga część konferencji rozpoczęła się zaraz po przerwie obiadowej i dotyczyła szkolnictwa we Francji, Stanach Zjednoczonych oraz Chinach. Podczas trwania drugiej sesji plenarnej uczestnicy wysłuchali następujących referatów: Noemie Becart, Primary school system in France - changes; Abby Liss, Positive aspects of primary education in America; Li Xiang, Chinese ideas for primary education. Podsumowaniem tej części była dyskusja porównawcza, zestawienie wysłuchanych przykładów z sytuacją edukacyjną w innych krajach. Uczestnicy dyskusji zastanawiali się, czy istnieje możliwość wcielenia omówionych praktyk edukacyjnych do własnych systemów szkolnych.

Wydarzenie zostało zamknięte podsumowaniem i wnioskami zarówno studentów, jak i wykładowców kierunków humanistycznych. Za pomocą metody aktywizującej uczestnicy mieli za zadanie wyrazić swoją opinię po otrzymaniu „dużej kostki”, a następnie przekazać ją następnej osobie. 
Osobiście uważam, że wielką zasługą organizatorów była niebywała atmosfera, która sprzyjała dialogowym relacjom w gronie studentów i wykładowców z całego świata. Spotkanie to było źródłem cennej debaty, która wynikła z potrzeby studentów praktyków, którzy mieli okazję podzielić się nowymi sposobami, które spróbują ulepszyć po powrocie do swoich szkół. Obserwując pozytywne nastawienie uczestników oraz władz uczelni, mam wielką nadzieję, że za rok będzie mi dane uczestniczyć w kolejnej edycji Międzynarodowej Studenckiej Konferencji Edukacyjnej „We are the Pioneers”.

Jakub Adamczewski 